УДК 629.4.033:62-233.3/.9

\title{
ВИЗНАЧЕННЯ ХАРАКТЕРИСТИК ЗАЧЕПЛЕННЯ ТЯГОВИХ ЗУБЧАТИХ ПЕРЕДАЧ 3 РЕАЛЬНИМИ ПРОФІЛЯМИ ЗУБЦІВ
}

\author{
Канд. техн. наук С.В. Бобрицький \\ ПРЕДЕЛЕНИЕ ХАРАКТЕРИСТИК ЗАЦЕПЛЕНИЯ ТЯГОВЫХ ЗУБЧАТЫХ \\ ПЕРЕДАЧ С РЕАЛЬНЫМИ ПРОФИЛЯМИ ЗУБЬЕВ
}

\section{Канд. техн. наук С.В. Бобрицкий \\ DETERMINATION OF DESCRIPTIONS OF HOOKING OF HAULING GEARINGS WITH THE REAL TYPES OF POINTS}

\author{
Cand. of techn. sciences S. Bobritskiy
}

В статті розглянута доиільність обгрунтованого підбору пар «шестерня-зубчате колесо» при перекомплектуванні ТЗП. Проаналізовані існуючі методи отримання характеристик зачеплення зубчатих коліс. Наведений новий підхід до визначення характеристик зачеплення зубчатих передач. Наведені приклади отриманих характеристик зачеплення ТЗП з визначеним зносом шестерні та колеса електропоїзда серї ЕР-2. Подано рекомендації щодо подальшого застосування запропонованого підходу для виконання обтрунтованого підбору парних зубчатих коліс.

Ключові слова: рухомий склад, електропоӥзд ЕР-2, тягова зубчата передача, зубчаті колеса, характеристики зачеплення, лінія зачеплення,

B статье обоснована целесообразность обоснованного подбора пар «шестернязубчатое колесо» при перекомплектащии ТЗП. Проанализированы существующие методы получения характеристик зацепления зубчатых колес. Приведен новый подход к определению характеристик зачепления зубчатых передач. Приведены примеры полученных характеристик зацепления ТЗП с определенным износом шестерни и колеса электропоезда серии ЭР-2. Представлены рекомендаџии относительно последующего применения предложенного подхода для выполнения обоснованного подбора парных зубчатых колес.

Ключевые слова: подвижной состав, электропоезд ЭР-2, тяговая зубчатая передача, зубчатые колеса, характеристики заџепления, линия зацепления.

In the article the necessity of the grounded selection of pair is grounded «cog-wheel-toothed wheel» at transposition TZP. It is marked that for the receipt of descriptions of hooking of pair of gear-wheels needed lengths, form and position of line of hooking. The existent methods of receipt of descriptions of hooking of gear-wheels are analysed. The lacks of existent methods are selected. New approach is resulted on determination of descriptions of hooking of gearings. The examples of the got descriptions of hooking of TZP are resulted with the certain wear of cog-wheel and wheel of electric train of series of ER-2. Presented recommendation in relation to subsequent application offered approach on determination of descriptions of hooking of the hauling gearings of the different degrees of wear of gear-wheels with the subsequent grounded selection of threadbare pair gear-wheels at implementation of repairs, and as a result, by the improved external of the hauling gearings environments

Keywords: rolling stock, electric train of ER-2, hauling gearing, gear-wheels, descriptions of hooking of gear-wheels, line of hooking. 
Вступ. Постановка проблеми у загальному вигляді та ії зв'язок 3 важливими науковими та практичними завданнями. Необхідність забезпечення техніко-економічних показників роботи залізничної галузі на високому рівні неухильно пов'язана 3 підвищенням експлуатаційної надійності тягового рухомого складу (ТРС). При цьому 3 урахуванням повільного впровадження нових серій ТРС та понаднормативну експлуатацію більшості інвентарного парку рухомого складу [1], особливої уваги заслуговують модулі конструкції ТРС, що безпосередньо впливають на безпеку руху. Одним з таких модулів $\epsilon$ екіпажна частина, до складу якої входить тяговий привод, однією з головних складових якого $є$ тягова зубчата передача (ТЗП).

Аналіз останніх досліджень i результатів. У ході попередніх досліджень [2,3] було встановлено, що внаслідок нерівномірного зносу шестерень та зубчатих коліс або виходу їх з ладу виникає необхідність перекомплектування ТЗП, тобто обгрунтованого підбору пар «шестерня-зубчате колесо» при виконанні деповських ремонтів. Здійснення підбору пропонується виконувати за найкращими характеристиками

геометричними (значення миттєвого передаточного відношення, кутових швидкостей та прискорень), якісними (коефіцієнт перекриття, коефіцієнт питомих ковзань, питомі тиски) та міцнісними (згинні та контактні напруження). Необхідно зазначити, що їх отримання пов'язане 3 визначенням довжини, форми і положення лінії зачеплення. Традиційні методики визначення лінії зачеплення [4] грунтуються на розгляданні зачеплення профілів зубців нових шестерні та колеса, тобто не враховуються ступені та особливості їх зносу.

Аналіз попередніх публікацій показав, що лінія зачеплення зношених зубчатих коліс суттєво відрізняється від лінії зачеплення нової пари [5]. Наведене вище обгрунтовує доцільність проведення науково-дослідних робіт, спрямованих на аналіз досліджень та розроблення методів щодо отримання лінії зачеплення зношених зубчатих коліс.

У роботі [6] для отримання реальної лінії зачеплення зношеної зубчатої передачі застосовувався метод обкатки моделей профілів, які виготовлялися 3 жорсткого матеріалу в масштабі збільшення. Положення точки контакту відмічалось на контактованих поверхнях та на нерухомій площині, відносно якої вони обертались. Такий метод наочний та дає можливість уникнути грубих помилок під час розрахунку зачеплення зношених профілів. Але йому притаманні недоліки: складність і трудомісткість виготовлення точних моделей профілів зубців, громіздкість моделі зубчатої передачі в зборі (так, при масштабі 10:1 модель зубчатої передачі електропоїзда серії ЕР-2 буде складати 4,8 м завдовжки та 2 м завширшки).

Аналітичний метод визначення координат контактних точок лінії зачеплення [7] потребує складних розрахунків та не дає достатньої точності.

Недоліки зазначених методів отримання лінії зачеплення вказують на необхідність розроблення нового підходу до ії визначення.

Мета статті і викладення основного матеріалу. Метою статті $\epsilon$ опис запропонованого підходу до визначення характеристик зачеплення зубчатих передач, відповідно до яких виконується обгрунтування підбору парних коліс ТЗП.

Запропонований підхід до розв'язання цієї задачі передбачає нижченаведену послідовність дій.

1. Отримуються цифрові описи профілів зубців з різними ступенями зносу за методикою [8].

2. Виконується побудова профілів зубців за отриманими цифровими описами в середовищі Компас-3D 3 відповідним масштабом збільшення. 
3. Виконується узгоджене прокручування зубчатих коліс у заданих напрямках 3 отриманням дискретних положень точок контакту профілів з перевіркою відсутності інтерференції (формування лінії зачеплення від початкової $\mathrm{B}_{1}$ до кінцевої $\mathrm{B}_{2}$ точок зачеплення).

4. Визначаються миттєве передаточне відношення $i$, кутові швидкості $\omega_{2}$ та прискорення $\varepsilon_{2}$.

5. Визначаються коефіціснт перекриття $\varepsilon$, максимальні питомі ковзання $\lambda_{1 \text { max }}$ і $\lambda_{2 \text { max }}$, питомі тиски $v$.

6. Проводиться коефіцієнта додаткового навантаження $k_{\Delta}$.
Запропонований

підхід

було використано в дослідженні з удосконалення технології ремонту ТЗП електропоїздів серії ЕР-2. Як приклад розглянуто отримані характеристики зачеплення ТЗП, яка складається 3 шестерні зі ступенем зносу 0,44 мм за хордою ділильного кола та зубчатого колеса, ступінь зносу якого складає 2,9 мм. Результати дослідження за пунктом 3 наведені на рис. 1, 2. Видно, що в передачі зі зношеними зубцями лінія зачеплення відрізняється за формою i положенням від нової.

3 рис. 3 видно, що в межах кута перекриття, на відміну від нової передачі $(i=3,17)$, існує непостійне значення передаточного відношення, а його коливання від 3,02 до 3,65.

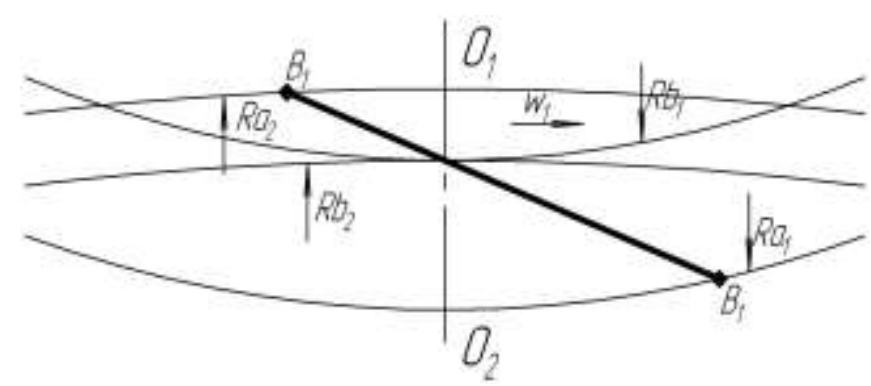

Рис. 1. Лінія зачеплення нових шестерні та колеса

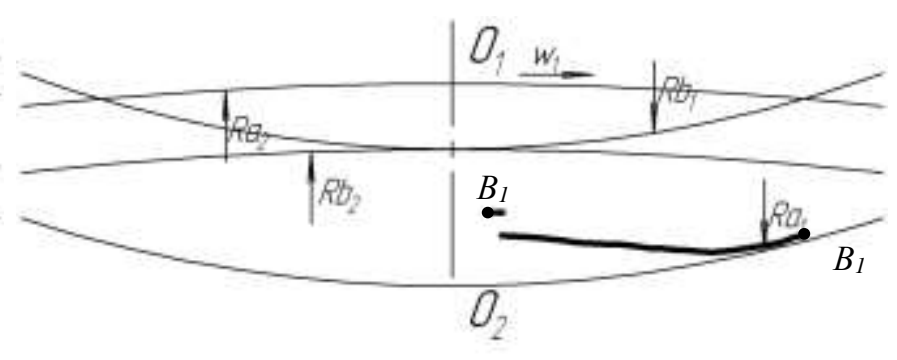

Рис. 2. Лінія зачеплення шестерні та колеса з визначеним зносом зубців

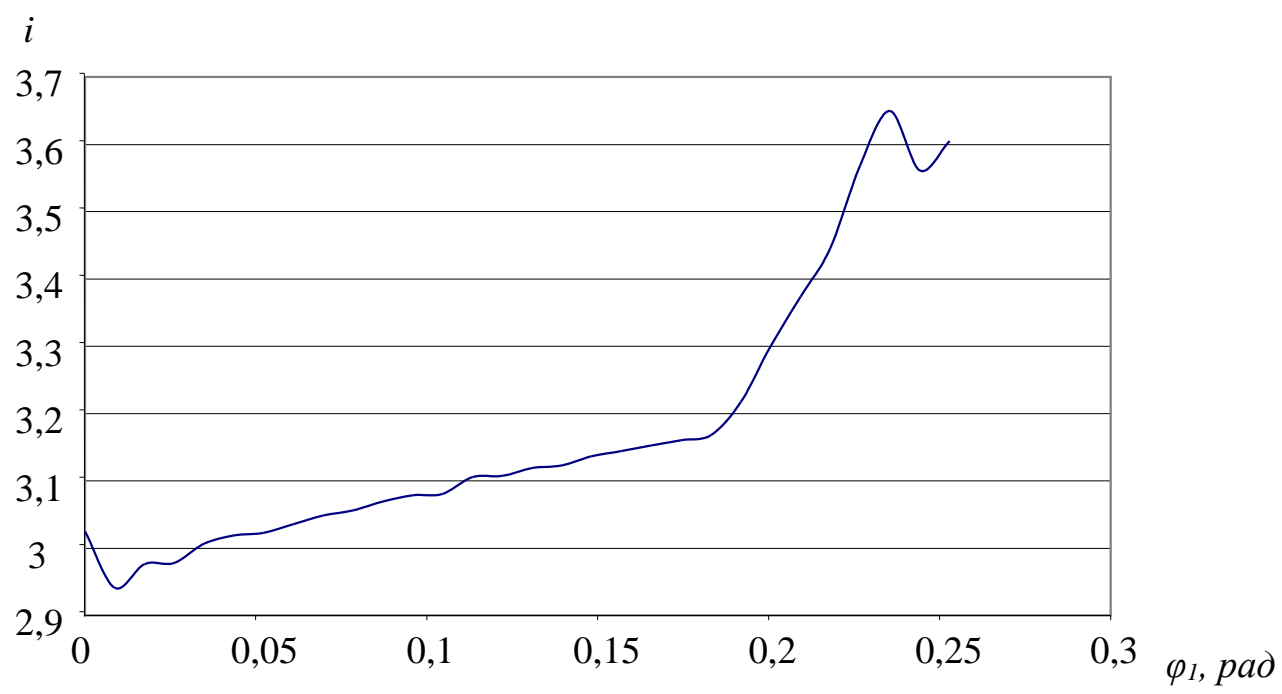

Рис. 3. Графік зміни миттєвого передаточного відношення в парі шестерні та зубчатого колеса з визначеним зносом 
3 аналізу графіків 4 і 5 видно, що кутова швидкість $\omega_{2}$ зменшується від $22,6 \mathrm{c}^{-1}$ до $18,5 \mathrm{c}^{-1}$, і має місце коливання кутових прискорень $\varepsilon_{2}$ в межах від 1250 рад $\cdot c^{2}$ до -1250 рад $\cdot c^{2}$.

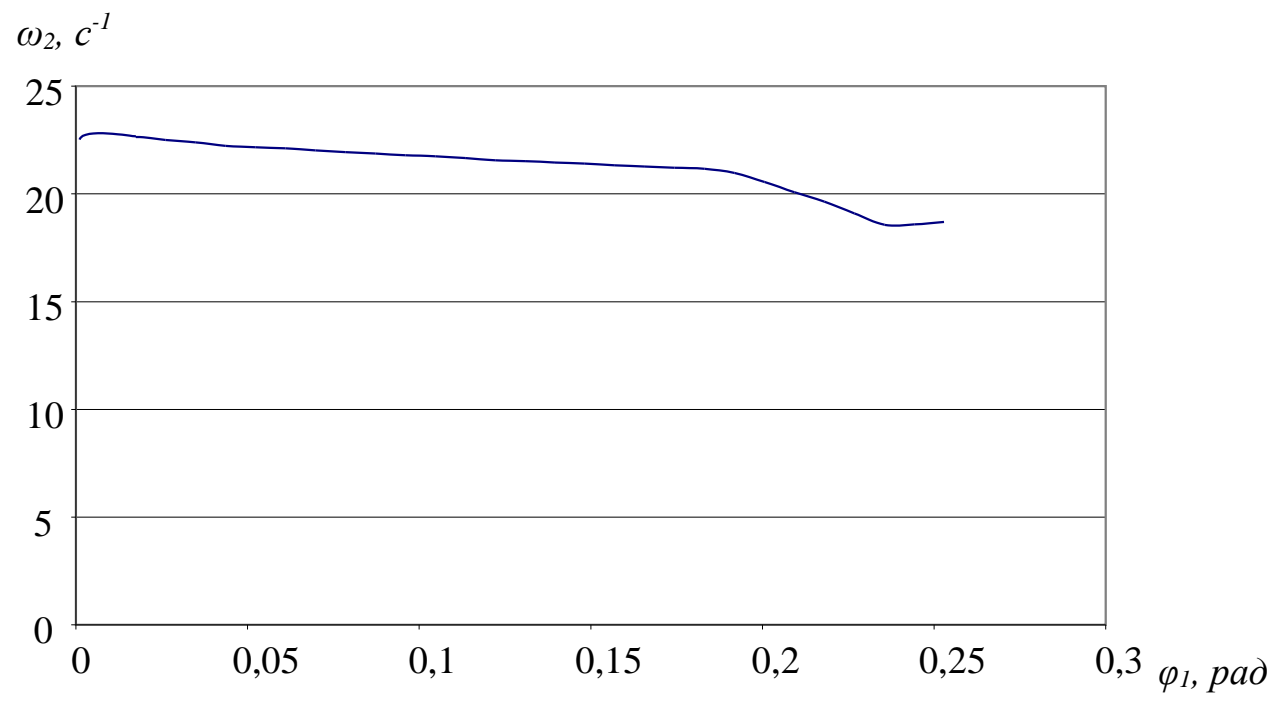

Рис. 4. Графік зміни кутової швидкості в парі шестерні та зубчатого колеса з визначеним зносом

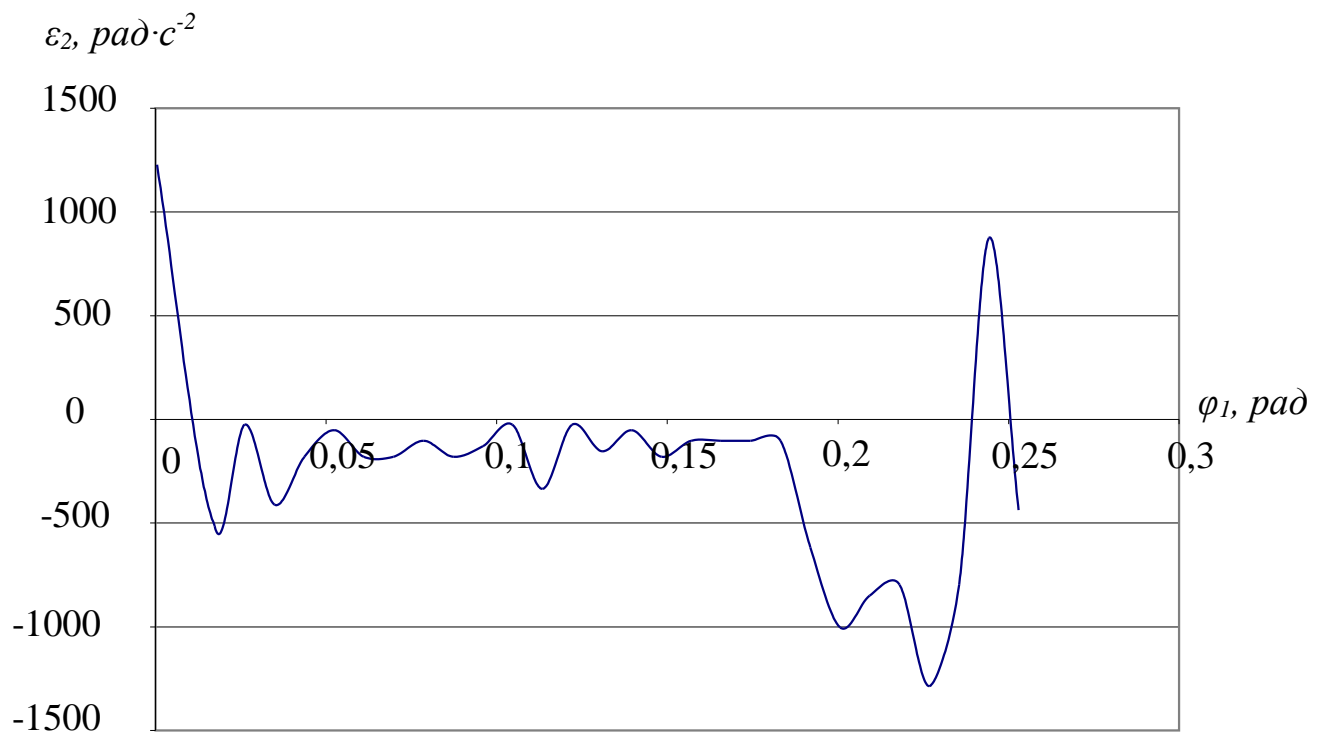

Рис. 5. Графік зміни кутового прискорення в парі шестерні та зубчатого колеса з визначеним зносом

Подальші розрахунки показали, що коефіцієнт динамічності складає $k_{\Delta}=1,7$, згинні напруження складають $\sigma_{F}=390$ МПа, контактні напруження складають $\sigma_{H}$ $=925$ МПа.
Порівняння отриманих характеристик зачеплення 3 відповідними характеристиками зубчатих передач 3 різним ступенем зносу дають змогу вибрати найкращий варіант пари «шестерня - зубчате колесо», який рекомендується для подальшої експлуатації у складі ТЗП. 


\begin{tabular}{llll}
\hline \hline Висновки i рекомендації шодо & результатів дає змогу проводити \\
подальшого використання отриманих & дослідження з визначення характеристик \\
результатів. Наведені в статті матеріали & зачеплення ТЗП з різними рівнями зносу \\
підтверджують доцільність використання & зубчатих коліс. Це дасть змогу здійснювати \\
запропонованого нового підходу до & обгрунтований підбір зношених парних \\
визначення характеристик зачеплення & зубчатих коліс для їх подальшої \\
зубчатих передач. Наявність отриманих & експлуатації.
\end{tabular}

\section{Список використаних джерел}

1. Стратегія розвитку залізничного транспорту на період до 2020 року [Електронний ресурс]: розпорядження Кабінету Міністрів України від 16. 12. 2009 р. №1555-р. - К., 2009. Режим доступу: http://zakon4.rada.gov.ua/laws/show/1555-2009-\%D1\%80.

2. Мороз, В.I. Обгрунтування перспективних напрямків підвищення експлуатаційної надійності тягових передач електропоїздів серії ЕР-2 [Текст] / В.I. Мороз, О.В. Братченко, С.В. Бобрицький // Зб. наук. праць. - Харків: УкрДАЗТ, 2009. - Вип. 111. - С.176-182.

3. Мороз, В.І. Нова методика визначення експлуатаційних зносів профілів зубців та підбору парних коліс тягових зубчатих передач [Текст] / B.I. Мороз, О.В. Братченко, С.В. Бобрицький // Зб. наук. праць. - Харків: УкрДАЗТ, 2010. - Вип. 117. - С. 12-16.

4. Кіницький, Я.Т. Теорія механізмів і машин [Текст]: підручник / Я.Т. Кіницький. - К.: Наук. думка, 2002. - 660 с.

5. Эстлинг, А.А. Повышение работоспособности тяговых зубчатых передач тепловозов [Текст]: автореф. дис. ... канд. техн. наук. / А.А. Эстлинг: спец. 05.22.07 “Подвижной состав и тяга поездов”. - С.Пб., 1995. - 20 с.

6. Старченко, В.Н. Исследование надежности, износа и динамики зубчатой тяговой передачи грузовых магистральных тепловозов [Текст]: автореф. дис. ... канд. техн. наук: спец. 05.22.07 “Подвижной состав и тяга поездов" / В.Н. Старченко. - Днепропетровск, 1977. $-22 \mathrm{c}$.

7. Онищенко, В.П. Прогнозирование долговечности тяжелонагруженных зубчатых передач на основе моделирования износа зубьев [Текст] / В.П. Онищенко. - Gliwice (Polska): Politechnika Slaska Z. 131 (1410) Mechanika, 1999. - 199 c.

8. Пат. 94015 Україна, МПК F16H 1/06 (2006.01). Спосіб визначення товщини зубця симетрично розташованого відносно опор прямозубого зубчатого колеса [Текст] / Мороз В.I., Братченко О.В., Бобрицький С.В. - №201009172; заявл. 21.07.2010; опубл. 25.03.2011, Бюл. № 6 .

9. Korn, G. Mathematical handbook. For scientist and engineers / G. Korn, T. Korn. - NY: McGrow-Hill Book Company, 1968. - 831 p.

Рецензент д-р техн. наук, професор А.П.Фалендиш

Бобрицький Сергій Владиславович, канд. техн. наук, кафедра механіки і проектування машин Української державної академії залізничного транспорту. Тел.: (057) 730-10-52.

Bobritskiy Sergiy Vladislavovich, cand. of techn. sciences department of mechanics and planning of machines Ukrainian State Academy of railway transport. Tel.: (057) 730-10-52 